\title{
ESPAÑA COMO CALEIDOSCOPIO. OBSERVACIONES DE INTELECTUALES ARGENTINOS SOBRE LA COMUNIDAD LETRADA HISPANOAMERICANA, SIGLO XIX
}

\author{
SPAIN AS A KALEIDOSCOPE. OBSERVATIONS OF ARGENTINE \\ INTELLECTUALS ABOUT THE HISPANIC-AMERICAN REPUBLIC \\ OF THE LETTERS, XIX CENTURY
}

\author{
Paula Bruno* \\ Consejo Nacional de Investigaciones Científicas y Técnicas (CONICET)/ \\ Universidad Torcuato Di Tella, Buenos Aires, Argentina
}

\begin{abstract}
RESUMEN: El artículo estudia las impresiones de intelectuales argentinos acerca de España esbozadas a lo largo del siglo XIX con el objetivo de ver cuáles eran los repertorios de ideas disponibles para pensar la conformación potencial de una comunidad de letrados hispanoamericanos. Para ello se organiza en secciones que revisan los siguientes cortes cronológicos: 1. 1810-1870; 2. 18701898; 3. 1898; 4. Fines de XIX-1905. Las voces seleccionadas permiten ver cómo fue evaluada España a la hora de ser considerada - o no- una referencia intelectual a ser reivindicada desde una nación de Hispanoamérica. Estas evaluaciones variaron en el largo plazo. Por este motivo, la noción de caleidoscopio se utiliza como metáfora para indicar qué matices y acentos postularon las miradas sobre España que se conformaron a lo largo de un siglo en sede argentina.
\end{abstract}

PALABRAS CLAVES: Intelectuales argentinos, Comunidad hispanoamericana, Cosmopolitismo intelectual, Vida cultural, Siglo XIX

\begin{abstract}
The article studies the Argentine intellectuals' impressions on Spain sketched throughout the 19th century with the aim of unfolding the available repertoires of ideas to think about the potential conformation of a Spanish-American republic of letters. To achieve this goal, it is organized in sections that review the following chronological segments: 1. 1810-1870; 2. 18701898; 3. 1898; 4. Late XIX-1905. The selected voices allow us to see Spain evaluations while it was being considered - or not - to be claimed as an intellectual reference for a Latin American nation. These evaluations varied in the long term. For this reason, the notion of a kaleidoscope is used as a metaphor to indicate what nuances and accents influenced the views on Spain that were shaped over a century in Argentinian lands.
\end{abstract}

KEYWORDS: Argentine intellectuals, Hispanic-American republic of the letters, intellectual cosmopolitism, Cultural life, XIX Century

* Correspondencia a: Paula Bruno. Universidad Torcuato Di Tella, Avenida Figueroa Alcorta 7350, CP: 1428, CABA, Argentina - pbruno@conicet.gov.ar - https://orcid.org/0000-0003-2877-617X

Cómo citar: Bruno, Paula (2020). «España como caleidoscopio. Observaciones de intelectuales argentinos sobre la comunidad letrada hispanoamericana, siglo XIX»; Historia Contemporánea, 63, 385-418. (https://doi.org/10.1387/hc.21104).

Recibido: 23 septiembre, 2019; aceptado: 31 enero, 2020.

ISSN 1130-2402 - elSSN 2340-0277 / (C) 2020 UPV/EHU 


\section{Introducción}

El artículo versa sobre las impresiones de figuras de la vida intelectual argentina acerca de España y las posibilidades de ser reivindicada como parte activa de una comunidad de letrados hispanoamericanos en el despliegue del siglo XIX ${ }^{1}$. Para ello, se organiza en secciones que revisan los siguientes cortes cronológicos y lineamientos: 1. 1810-1870: se pasa revista a voces representativas que marcaron los paradigmas interpretativos sobre España en las décadas posteriores a la ruptura del lazo colonial; 2. 1870-1898: se recuperan y analizan las voces de intelectuales que plantearon posturas de aceptación y rechazo frente a los referentes intelectuales y las coordenadas culturales españolas; 3 . 1898: se revisa la coyuntura acompasada por la guerra entre España y Estados Unidos como un momento propicio de condensación de imágenes sobre las potencialidades y límites de trazar puentes entre España y sus ex-colonias a la hora de pensar en el acervo intelectual de tierras americanas; 4. Fin de siglo XIX-1905: se presentan voces que en el cambio de centuria se plantearon la posibilidad de pensar identidades de referencia intelectual más allá de los límites nacionales en un contexto argentino de auge del nacionalismo cultural y los proyectos nacionalizantes ${ }^{2}$.

El objetivo principal es dar cuenta de los repertorios de ideas que convivían en tensión entre los letrados argentinos a la hora de evaluar tradiciones en las que inscribirse y de postular la posibilidad de generar una comunidad transnacional, de corte hispanoamericano, en la que convivieran letrados de ambos lados del Atlántico.

Las voces de intelectuales y políticos argentinos que plantearon acercamientos y distanciamientos respecto España variaron en el largo plazo ${ }^{3}$.

${ }^{1}$ La noción de «intelectuales argentinos» se utiliza en este texto para referir a figuras de la vida letrada argentina; sin embargo, por las propias dinámicas históricas del siglo XIX (atravesada por exilios, migraciones, enfrentamientos bélicos, entre otros procesos), algunas de las figuras aquí tratadas no nacieron en lo que es hoy el territorio nacional argentino; es el caso de Eduardo Wilde (nacido en Tupiza, Bolivia), Miguel Cané (nacido en Montevideo, Uruguay) y José Ingenieros (nacido en Palermo, Sicilia, Italia). Además, se presta aquí atención a ciertas a voces que, aunque oriundas de otras latitudes, desplegaron parte de sus trayectorias en Argentina, entre las que se destacan Rubén Darío (nacido en San Pedro de Metapa - hoy Ciudad Darío-, Nicaragua) y Paul Groussac (nacido en Toulouse, Francia, y afincado en Argentina desde sus 18 años).

2 Bertoni, 2001; Devoto, 2002.

3 Figallo, 2014; Rivadulla Barrientos, 1992; Sánchez Mantero et al., 1994. 
$\mathrm{Al}$ respecto, se han estudiado con frecuencia las primeras décadas posteriores a la revolución de 1810, en las que se generó una intensa ola de antihispanismo, que cristalizó en imágenes y tópicos recurrentes hacia la década de 1830. Por su parte, los estudios dedicados a analizar el rol de los intelectuales en la conformación de la identidad nacional argentina han revisado de manera sistemática las voces que hacia el Centenario de la revolución, conmemorado en 1910, reivindicaron el legado hispánico que habilitó recuperaciones de la «madre patria» integradas a los relatos de «invención» de la nación ${ }^{4}$.

Se propone aquí una visión de largo plazo atenta a la revisión de las décadas intermedias entre estos dos momentos. Las mismas han sido foco de interés central en los estudios sobre la emigración de españoles en Argentina, la conformación de asociaciones étnicas, y el rol de las elites españolas asentadas en tierra americana, entre otras líneas de estudio ${ }^{5}$; acompañando estas tendencias, se revisan aquí voces de figuras que pensaron en las potencialidades de la conformación de una república de las letras hispanoamericana. Con este objetivo, se relevan y ponderan las voces de un elenco de letrados que en estas décadas generaron un entramado de interpretaciones sobre la antaño metrópoli. A su vez, se hace foco en los intelectuales que desde la década de 1880 , aproximadamente, postularon miradas que excedieron las intenciones nacionalizantes y optaron, en cambio, por evaluar opciones identitarias más allá de las fronteras nacionales ${ }^{6}$.

Con este fin, se han consultado, por un lado, las miradas que surgieron a partir de viajes por España y desde los espacios provistos por la vida intelectual y diplomática. A su vez, las que surgieron en torno a grandes hitos de escala transnacional, como la I Conferencia Panamericana (Washington, 1889-1890), los festejos del IV Centenario de la llegada de Cristóbal Colón a tierras americanas (1892), y la guerra entre España y Estados Unidos (1898). Por otro lado, se han sumado indicios que permiten ver algunos momentos clave en la configuración de repertorios y tramas interpretativas respecto de España en sede argentina.

\footnotetext{
${ }^{4}$ Pueden verse, entre otros: Devoto y Barbero, 1983; Lojo, 2011; Payá y Cárdenas, 1978.

5 Entre otros: Bernasconi y Frid, 2006; Fernández y Moya, 1999; García Sebastiani, 2011; Moya, 2004.

${ }^{6}$ Las voces aquí relevadas han sido estudiadas en la historiografía latinoamericana y española para abordar capítulos específicos de la vida cultural. En este caso, proponemos revisarlas en una perspectiva de largo plazo y analizar sus miradas sobre las posibilidades y límites de la existencia de una comunidad letrada hispanoamericana.
} 


\section{0-1870: España, «la nación más atrasada de Europa» ${ }^{7}$}

Luego de las rupturas de los lazos coloniales, acaecidas entre $1810 \mathrm{y}$ 1824 , en los antiguos dominios de la monarquía española comenzaron a definirse procesos de independencia cuyo impacto abarcó desde aspectos de índole geográfica y política hasta reordenamientos culturales ${ }^{8}$. En varias excolonias, la definición de las identidades de las nuevas naciones se gestó por la negativa; es decir, surgió como un imperativo de diferenciación respecto de la antigua metrópoli. De este modo, emancipación y deshispanización parecían ser dos caras de la misma moneda a la hora de proyectar las nuevas naciones ${ }^{9}$.

En la actual Argentina, desde 1810, España era leída en términos de enemiga y, por lo tanto, se consideraba necesario erradicar los vestigios coloniales y descartar las herencias recibidas. En este contexto, acompasado por las guerras desatadas luego de la revolución, surgió una tendencia que algunos autores sintetizaron con la expresión «hispanofobia de la clase intelectual argentina» ${ }^{10}$. La misma se vio profundizada por los miembros del primer grupo de publicistas destinados a pensar la nación, la llamada «generación del 37», que mantuvieron, por lo menos hasta la década de 1870 , miradas de sesgo negativo sobre España ${ }^{11}$.

De este modo, las interpretaciones ofrecidas por los publicistas de estas décadas respecto de las revoluciones y los sucesos posteriores se forjaron al calor de un contexto en el que la búsqueda de causas válidas para que las excolonias rompieran el lazo colonial se encontró en las estructuras impuestas desde la metrópoli; la misma había generado, según estas miradas, dinámicas asfixiantes en el plano económico y político, pero también en el cultural, que tornaban imposible continuar en situación de sometimiento. Con estos acentos, por ejemplo, a la hora de justificar la ruptura con España, Esteban Echeverría señalaba: «al abrirse el siglo actual, la España era la nación más atrasada de Europa. Nada quedaba a su orgullo sino el recuerdo de su pasado grande y poderoso.

${ }^{7}$ La expresión pertenece a Esteban Echeverría y la referencia a la cita textual se encuentra en esta sección.

${ }^{8}$ Halperin Donghi, 1985.

9 Rama, 1982; Zuleta Álvarez, 1988.

10 Arrieta, 1948, pp. 77 y 78.

11 Myers, 2005. 
En su diadema regia solo brillaba con lustre una joya conquistada por el brazo de sus aventureros paladines. Esa joya era la América» ${ }^{12}$.

En un sentido complementario, Domingo Faustino Sarmiento, en su ensayo célebre Facundo (1845), destacaba la frágil legitimidad de España para retener el control sobre sus colonias americanas:

«la España, esa rezagada a la Europa, que echada entre el Mediterráneo y el Océano, entre la Edad Media y el siglo XIX; unida a la Europa culta por un ancho istmo, y separada del África bárbara por un angosto estrecho, está balanceándose entre dos fuerzas opuestas, ya levantándose en la balanza de los pueblos libres, ya cayendo en la de los despotizados; ya impía, ya fanática, ora constitucionalista declarada, ora despótica impudente: maldiciendo sus cadenas rotas, a veces ya cruzando sus brazos, ya pidiendo a gritos que le impongan el yugo, que parece ser su condición y modo de existir» ${ }^{13}$.

Un tópico destinado a perdurar surgió propiciado por estas consideraciones, y otras afines: el del atraso - político, cultural, económico y social - como el factor que explicaba la justificada irreverencia de las naciones americanas que buscaban torcer su destino y abrirse paso a la era del progreso en el período de las revoluciones e independencias. Este tópico se vio reforzado en un libro canónico para pensar la vida intelectual del siglo XIX argentino, Viajes, del mencionado Sarmiento, quien, al llegar a España en 1846, subrayó:

«Esta España, que tantos malos ratos me ha dado téngola, por fin, en el anfiteatro, bajo la mano; la palpo ahora, le estiro las arrugas, y si por fortuna me toca andarle con los dedos sobre una falla a fuer de médico, aprieto maliciosamente la mano para que le duela, como aquellos escribanos de los tribunales revolucionarios o de la inquisición de antaño» ${ }^{14}$.

Sarmiento inauguraba, por lo menos en el escenario intelectual argentino, la ocurrencia de pensar en las corridas de toros como una maqueta que sintetizaba en miniatura todos los rasgos del pueblo español. Asimilaba esta práctica cultural con la de los circos romanos, y no dudaba en encontrar allí la quintaesencia de la sociedad ibérica:

\footnotetext{
12 Echeverría, 1874, p. 243.

13 Sarmiento, 1999 (1845), pp. 27 y 28.

14 Sarmiento, 1997 (1851), pp. 127 y 128.
} 
«Por sus costumbres y su espíritu, el pueblo español es el pueblo más romano que existe hoy día. Todos sus males le vienen de ahí: enemigo del trabajo, guerrero, heroico, tenaz, sobrio y apasionado por los espectáculos todavía pide panen et circenses [...] Sobre la plaza de toros el pueblo español es grande y sublime; es pueblo soberano y rey también. Allí se resarce, con emociones más vivas que las del juego, las privaciones que a su pobreza lo condena, y si esta diversión puede ser acusada de barbarie y de crueldad, es preciso convenir, sin embargo, que no envilece al individuo como la borrachera, que es el innoble placer de todos los pueblos del norte» ${ }^{15}$.

Quedaba así cristalizada una imagen que convertía los espectáculos taurinos en sinécdoque para dar cuenta de todos los aspectos negativos de la sociedad española. En general, las observaciones que autores como Echeverría y Sarmiento ofrecieron se inscribieron sin fisuras en los lineamientos generales de la hispanofobia ${ }^{16}$; las caracterizaciones sobre la sociedad - descripta como casi bárbara e improductiva-, sus dinámicas religiosas - consideradas fanáticas - , una economía sin impulsos industriales, y las preferencias políticas de su sociedad no hacían más que sumar consideraciones sobre el letargo y la desidia general.

Estas miradas solían acentuarse a la hora de ponderar la valía de los aportes intelectuales españoles que podían ser potencialmente retomados en América. En este punto también los juicios eran pesimistas. El ya citado Esteban Echeverría destacaba: «en la obra del genio español nada había de cosmopolita y humanitario. En los hechos de sus conquistas, en sus concepciones y producciones literarias, llevaba el sello de su carácter adusto e insocial, de su egoísta y rudo nacionalismo» ${ }^{17}$. Juan Bautista Alberdi, por su parte, al estudiar temas ligados a la jurisprudencia, subrayaba: «la España pues no sabe de derecho, no sabe de sus principios, ni de su historia. Sin filosofía, no ha podido saber de derecho; sin derecho, no ha podido saber de jurisprudencia ${ }^{18}$. Con acentos todavía más enfáticos, Sarmiento se preguntaba cómo era posible que no existieran en España «escritores, ni sabios, ni políticos, ni economistas, ni historiadores, ni cosa que lo valga ${ }^{19}$.

\footnotetext{
15 Sarmiento, 1997 (1851), pp. 139 y 140.

16 Sepúlveda Muñoz, 2005, pp. 225 y 243.

17 Echeverría, 1874, p. 243.

18 Alberdi, 1937, p. 131.

19 Sarmiento, 1997 (1851), p. 128.
} 
En este punto, el rechazo a España se consideraba, a la vez, punto de partida para la forja de nuevas tradiciones culturales para el futuro de las naciones que habían sido oprimidas como colonias. La fórmula general propuesta por varios letrados puede resumirse en estos términos: la suerte de la ex-América española podía encarar un despliegue optimista si se dejaban atrás las herencias de la metrópoli y se desarrollaban en el Río de la Plata otras líneas de pensamiento. En este sentido, Juan Bautista Alberdi, por ejemplo, no dudaba en hacer un llamamiento para dar forma a un «pensamiento americano» autónomo de las tradiciones hispánicas ${ }^{20}$. En dirección complementaria, Juan María Gutiérrez, destacaba que más allá de la lengua, nada había en España para recuperar ${ }^{21}$. De este modo, el atraso y la desidia para salir de él se convirtieron en estas décadas en las explicaciones dilectas para repudiar el pasado colonial. Estas consideraciones se mantuvieron vigentes - con acentos no siempre idénticoshasta, por lo menos, entrada la década de $1870^{22}$.

En suma, entre 1810 y 1870, aproximadamente, las voces de mayor gravitación de la vida cultural argentina - entre las que se cuentan las de Domingo Faustino Sarmiento, Esteban Echeverría y Juan Bautista Alberdi- caracterizaron a España como una nación enemiga de la que debía tomarse distancia. Si los nuevos territorios emancipados pretendían dar forma a nuevas matrices intelectuales americanas, las rupturas con la exmetrópoli parecían ser un imperativo. Parecían clausuradas las posibilidades de diálogo entre letrados de la nueva nación y la exmetrópoli.

\section{0-1898: España, «la nación ilustre que nos ha dado su sangre generosa y su incomparable idioma» ${ }^{23}$}

Generalmente, se ha indicado que los intelectuales argentinos de las décadas finales del siglo XIX tenían una actitud afrancesada en sus modales, sociabilidades y lecturas. Los propios protagonistas de la época subra-

\footnotetext{
20 Alfón, 2008, p. 53.

21 Para un tratamiento de estos tópicos en otros países de América Latina, puede verse Rama, 1982.

22 Algunas de las figuras mencionadas en esta sección cambiaron sus puntos de vista hacia esta década, es el caso de Juan Bautista Alberdi. Véase Arrieta, 1948, p. 167.

${ }^{23}$ La expresión pertenece a Calixto Oyuela y la referencia textual se indica en esta sección.
} 
yaban su afrancesamiento; apuntaba Miguel Cané, por ejemplo, que los letrados de su generación se habían nutrido «casi exclusivamente de los libros franceses y en el gusto persistente y legítimo por la literatura de ese país» ${ }^{24}$. Testimonios con estos tintes generaron una idea compacta sobre estas décadas en las que, sin embargo, algunas figuras de la vida intelectual argentina manifestaron gestos de aceptación ante matrices culturales que tenían seno en España ${ }^{25}$.

Algunos hitos en este sentido se desplegaron durante la década de 1870. Por ejemplo, la publicación por parte de Paul Groussac de un artículo sobre José de Espronceda de amplia repercusión ${ }^{26}$. En el mismo, señalaba que en el poeta español se encontraban lecciones para ser retomadas por las jóvenes generaciones de letrados argentinos. Contemporáneamente, las obras históricas de figuras como Bartolomé Mitre, inauguraron una lectura de la vida colonial en el ámbito rioplatense que daba cuenta de las particularidades de estas geografías a la luz de los diferenciales entre estos territorios y otras experiencias coloniales ${ }^{27}$.

Sin embargo, pese a algunos gestos de apertura a la recepción de literatura española y a una predisposición por repensar el rol histórico de España en tierras americanas, aquellas figuras que vindicaban alguno de los rasgos culturales españoles eran generalmente consideradas «tradicionalistas» o «hispanistas» y caracterizadas como retrógradas por sus contemporáneos. Reiteradas veces estas voces se encontraban asediadas en debates en los que sus argumentos eran descalificados por ponderarse vetustos. Entre los nombres más mencionados dentro de estas descripciones se cuentan los de Calixto Oyuela y Santiago Estrada. El primero, en una intervención en la que comentaba la producción poética americana, ponía en acto un gesto recurrente:

«No soy de los contaminados con injustas prevenciones ni con odios, hoy solo dignos de corazones mezquinos, contra España; antes tengo por ella verdadero cariño, y deseo ardientemente, aun para bien de nosotros mismos, que se estrechen los vínculos que deben unirnos con la nación ilustre que nos ha dado su sangre generosa y su incom-

24 Cané, 1919, p. 62.

${ }^{25}$ He revisado críticamente las caracterizaciones clásicas y generales sobre la elite cultural argentina del giro del siglo XIX al XX en Bruno, 2012.

${ }^{26}$ Groussac, 1871.

27 Devoto y Pagano, 2009, pp. 13-72. 
parable idioma [...] Más aún: los nombres de Cervantes, de Calderón y otros insignes peninsulares, suscitan en mí no sé qué sentimiento de orgullo y amor. Como si se tratara de glorias propias; pero todo esto sin descender un ápice mi dignidad de americano. Por lo cual, si las modernas declamaciones contra España me parecen vacías y torpes, no así los gritos de indignación, hijos del fuego sagrado de libertad e independencia que ardía en el alma de nuestros padres». ${ }^{28}$

La cita es reveladora. Los motivos por los que a comienzos de la década de 1880 un intelectual debía justificar su postura de letrado americano que no renegaba de la cultura de España tenía que ver con que habían trascurrido décadas en las que no era posible pronunciarse a medias tintas sobre este punto. A lo largo de la década de 1880, en cambio, se concretaron varias intervenciones que mostraron que las posturas de resistencia ante España comenzaban a ser menos categóricas. Esta variación encontraba tierra fértil, de acuerdo a la hipótesis de trabajo aquí sostenida, en las opciones que se abrían a la hora de pensar en una comunidad intelectual y de la lengua que se veía paulatinamente propiciada por la convivencia entre los hombres de letras latinoamericanos y españoles.

Así lo constatan observaciones de viajeros y referentes intelectuales argentinos. Si en las mencionadas crónicas de Sarmiento la experiencia de la travesía parecía confirmar los presupuestos y prejuicios sobre la antigua metrópoli, registros de la década de 1880 mostraba otra predisposición en los observadores que recorrían España ${ }^{29}$. Los desplazamientos y los cargos diplomáticos abrían, además, la chance de interactuar con figuras de la vida cultural peninsular y establecer afinidades. Así lo percibía Vicente Quesada, quien escribió en 1882: «los americanos que visitan España, aunque extranjeros, se encuentran, puede decirse, en el hogar de la misma familia, pues el alma mater se siente donde quiera que se escucha en la península la rica y pomposa lengua de Cervantes, y se recibe la hidalga acogida, la simpática atracción, casi el afecto de sus hombres de letras» ${ }^{30}$.

Los viajes para recorrer escenarios europeos, asistir a eventos de repercusión internacional, o desplegar funciones diplomáticas ofrecieron la posibilidad de que los literatos argentinos pudiesen entablaran diálogos

28 Oyuela, 1882, p. 564. 2002.

${ }^{29}$ Una aproximación panorámica sobre estos temas puede encontrarse en Zulueta,

${ }^{30}$ Quesada, 1881,p. 672. 
con algunos pares de la península ${ }^{31}$. Esta tendencia fue propulsada por algunas figuras claves. Así, por ejemplo, el intelectual y diplomático Martín García Mérou, durante una estadía en Madrid con responsabilidades diplomáticas, devino un puente entre algunas novedades de la literatura española y los letrados argentinos. A la vez que se ocupaba personalmente de enviar obras y comentarios sobre autores peninsulares a distintas figuras con el objetivo de dar a conocer las novedades españolas entre sus contemporáneos, buscaba destacar la valía de algunos escritores desprestigiados en Argentina. Así, por ejemplo, escribía a Miguel Cané: «soy íntimo amigo de Menéndez y Pelayo que me aprecia y me distingue más de lo que yo esperaba. No puede usted imaginarse la sorpresa que he tenido al conocerlo. Está muy lejos de ser el espíritu retrógrado y fanático que uno supone». En el mismo sentido, destacaba que Menéndez y Pelayo era «un prodigio de genio y de erudición ${ }^{32}$.

Si la estancia diplomática madrileña de Martín García Mérou habilitaba este tipo de contacto y difusión, el hecho de que él mismo escribiera una novela ambientada en Madrid - Ley Social, 1885 - y que varios medios de prensa comentaran su obra, funcionó en sentido inverso: un escritor americano comenzaba a ser reconocido en los cenáculos culturales de la península ${ }^{33}$.

Otras figuras que se afincaron en España colaboraron también en la construcción de estas nuevas tramas de relaciones entre referentes de la vida cultural de los dos lados del Atlántico. Es el caso de Santiago Estrada, mencionado ya como una figura criticada por «hispanista», que vivió varios años en Madrid en la década de 1880 y entabló vínculos duraderos con actores, dramaturgos y escritores, entre los que se destaca Rafael Calvo; Estrada escribió una cantidad considerable de críticas sobre el repertorio de Calvo que permitieron que fuera reconocido en Buenos Aires y otras capitales de América Latina ${ }^{34}$.

Un vínculo que cabe relevar especialmente es el entablado por Gaspar Núñez de Arce y Miguel Cané; el último narra que en tanto representante de Argentina en Madrid (ejerció estas funciones hacia mediados de la década de 1880) fue visitado por Núñez de Arce, quien lo invitó a pronunciar una conferencia en el Ateneo de Madrid, con motivo de las prepa-

31 Colombi, 2004.

32 Carta de García Mérou a Miguel Cané, citada en Sáenz Hayés, 1955, p. 291.

33 Bruno, 2018a.

34 Estrada, 1883. 
raciones de las celebraciones del IV Centenario de 1492. La crónica que Cané escribe sobre su encuentro con el autor de Gritos del combate es ilustrativa en varios aspectos. Sobre la visita inicial que el mismo le hace en su domicilio, destaca que lo sorprendió la llaneza del trato; cuenta que, una vez recibido el visitante, se presentó en los siguientes términos: «soy presidente del Ateneo y vengo a pedir [...] Vamos en breve a celebrar una fiesta precursora de la gran solemnidad del centenario de Colón» ${ }^{35}$. Acto seguido, le solicitó al representante argentino que preparara una conferencia para este evento. La respuesta de Cané fue negativa y contundente, dado que siempre había pensado que «dos de los hombres más fatales que ha tenido España han sido Colón y Felipe el Hermoso» ${ }^{36}$. Al final de la reunión, el diplomático argentino le sugirió a Núñez de Arce que contactara para que dicte la conferencia a su colega Juan Zorrilla de San Martín, que cumplía funciones como representante de Uruguay ${ }^{37}$.

En la descripción de este encuentro, más allá de lo anecdótico, se destacan varios aspectos: en primer lugar, la sorpresa de Cané a la hora de describir el encuentro entre un escritor y diplomático argentino y un letrado español en términos de trato de igual a igual; por otro lado, se deja ver cómo Miguel Cané no dudaba en señalar que, en particular, no sentía animadversión por España, pese a que juzgaba negativa la influencia de algunas figuras que eran reivindicadas en el marco de la preparación de los festejos ligados al IV Centenario. Por último, se ve en acción la intención de algunas figuras españolas que pretendían construir puentes con letrados americanos en el marco de los mencionados festejos. Esta pretensión cristalizó en varias iniciativas conocidas, entre las que la historiografía ha destacado la conformación de la Unión Iberoamericana, lanzada oficialmente en Madrid en 1885, y descripta por varios autores como una asociación en la que políticos e intelectuales de España bregaron por estrechar vínculos con letrados americanos con el objetivo de dar forma a una comunidad hispánica ${ }^{38}$.

35 Cané, 1919, p. 28.

36 Cané, 1919, p. 32.

37 La conferencia fue, de hecho, dictada por Zorrilla de San Martín, letrado uruguayo destacado del cambio del siglo XIX al Xx. Véase al respecto: Cagiao Vila, 2018.

${ }^{38}$ La Unión Iberoamericana es caracterizada de distintas formas en la bibliografía disponible. Mientras que en algunos casos se la describe como un espacio de sociabilidad política y literaria, en otros se pone en énfasis en los intereses privados que operaron en la configuración de la misma. Pueden consultarse, entre otros: de Zuleta, 1992; Sepúlveda Muñoz, 1991. 
$\mathrm{Si}$ algunas iniciativas parecían tener ecos optimistas entre intelectuales argentinos, otras, en cambio, eran miradas con sospecha. El mencionado Cané señalaba, por ejemplo, su distancia con «las exigencias de la Academia Española, la pobreza de su autoridad. La sonrisa universal que han suscitado algunas de sus preceptos» ${ }^{39}$. Esta observación revela un juicio bastante extendido entre sus contemporáneos ${ }^{40}$. Es reveladora, además, porque da cuenta de un clima que se vivía en Argentina a la hora de evaluar iniciativas de instituciones españolas. Mientras que figuras letradas de Chile (José Victorino Lastarria y Andrés Bello, por ejemplo), México (como Alejandro Arango y Escandón) y Colombia (entre ellos José Manuel Marroquín), aceptaban el honor de formar parte de la institución sin dudarlo, varios intelectuales argentinos rechazaron la designación - entre los casos más mencionados, se encuentra el de Juan María Gutiérrez - como gesto de resistencia ante la exmetrópoli y sus imposiciones culturales. Pese a ello, cabe aclarar que, mientras que ciertas figuras declinaron el convite a ser miembros de la institución, otras hicieron de la aceptación y del título «miembro de» parte de su prestigio intelectual, este es el caso de los ya mencionados Santiago Estrada y Vicente Quesada.

En simultáneo al planteo de estas tensiones, en varias figuras se constata una flexibilización del punto de vista sobre España, vía la reivindicación de la comunidad de la lengua y la oportunidad de generar diálogos interpares entre hombres de letras de las dos naciones ${ }^{41}$. Entre las voces que sostuvieron estas ideas en Argentina, se destaca la de Eduardo Wilde, que, en un libro publicado en 1892, apuntaba con optimismo: «la España me ha hecho la impresión de un pueblo que renace. He visto en todas partes cierto afán, cierto movimiento, como si estuviera por revelarse la decisión de actuar al despertarse después de un sueño reparador» ${ }^{42}$.

En el contexto de un viaje, Wilde observaba que, pese a pertenecer a una prosapia sajona, sentía «estar vinculado a España por la tradición, por la lengua, por los amigos españoles [...], por la admiración de algunas de sus altas calidades de índole nacional» ${ }^{43}$. En el marco de estas considera-

39 Cané, 1919, p. 62.

40 Puede verse también López, 1915, p. 54.

41 Distintas miradas sobre este tema pueden verse en los trabajos compilados en Dahmen et al., 2006.

42 Wilde, 1892, p. 386.

${ }^{43}$ Wilde, 1892, p. 388. 
ciones de tono conciliador se esbozaba con nitidez la noción de «comunidad del idioma ${ }^{44}$. La lengua común parecía ser un elemento de ligazón reconocido: «nadie es extranjero donde hablan su lengua, aun cuando no medie relación de padres a hijos por razones de colonización como media entre españoles y americanos del Sud ${ }^{45}$.

Junto con estas apreciaciones, Wilde proponía complejizar el tópico del atraso español. Desde su perspectiva, el mismo se debía, en parte, al peso de la monarquía y la Iglesia Católica, pero también a lo que consideraba una ausencia de dirigencias políticas que pudieran ajustarse a las coordenadas que el fin de siglo marcaba en las agendas internacionales ${ }^{46}$. La sociedad española, por su parte, no generaba en Wilde juicios severos. Por ejemplo, mostraba distancia del relato sarmientino en su evaluación sobre las corridas de toros; desde su perspectiva, se trataba de un asunto de gusto y de conducta moral: «repudio y detesto semejante diversión; me parece indigna de la nobleza humana, cruel y salvaje» ${ }^{47}$, pero aquí se detenían sus sentencias; justo antes de dar paso a generalizaciones sociologizantes.

A modo de balance general, Wilde señalaba que España estaba encaminada para su regeneración. Encontraba evidencias para sostener este argumento en la vitalidad de la cultura letrada. No dudaba en señalar, marcando clara distancia con lecturas que lo precedían: «no hay un género literario en que la España no pueda presentar maestros en todas las épocas y clásicos notables, poetas, romancistas, filósofos, historiadores, viajeros, jurisconsultos, autores dramáticos y predicadores» ${ }^{48}$. Estas consideraciones quedaban coronadas por los elogios dedicados a Biblioteca Nacional de Madrid como una institución destinada al conocimiento que debía convertirse en un faro para todos los miembros de la vida intelectual de habla hispana ${ }^{49}$.

En síntesis, la existencia de una comunidad de la lengua y la posibilidad de trazar puentes culturales entre letrados de ambos lados del Atlántico quedó esbozada en la mirada de varios intelectuales argentinos en las décadas de 1880 y 1890 . De este modo, puede argumentarse que si bien

\footnotetext{
44 Wilde, 1892, p. 389.

45 Wilde, 1892, p. 389.

46 Wilde, 1892 , p. 381 y 382.

47 Wilde, 1892, p. 389.

48 Wilde, 1892, p. 401.

49 Wilde, 1892 , p. 420.
} 
algunas de las intenciones del IV Centenario para estrechar los lazos entre las naciones hispanoamericanas y España no siempre tuvieron los efectos esperados por las instituciones españolas ${ }^{50}$, algunas voces manifestaron la intención de establecer vínculos y habilitar los canales de lo que AnneMarie Thiesse ha denominado «cosmopolitismo intelectual», gesto característico de los letrados que establecían relaciones con sus pares de otras latitudes en el marco de los procesos de consolidación de identidades nacionales $^{51}$.

A inicios de 1890, por su parte, se abría un nuevo escenario. A la vez que desde España las preparaciones para los festejos del IV Centenario estaban en despliegue, nuevas preguntas sobre su relación con las Américas habían surgido de manera contundente en un escenario paralelo: la I Conferencia Panamericana, realizada en Washington en 1889-1890. Por un lado, este evento dio paso a la visualización de Estados Unidos como un peligro para el continente americano; la idea de que surgía una nueva metrópoli con ansias imperialistas reverberaba en las imágenes de aquella España de la expansión ultramarina, considerada colonizadora y atrasada ${ }^{52}$. Por otro, y en contraposición a estas miradas alarmadas, la idea de que España podía oficiar como dadora potencial de un pasado con espesor para las naciones latinoamericanas comenzó a ganar terreno entre varios intelectuales, como se argumenta en la siguiente sección.

En suma, en esta segunda estación temporal que se desplegó entre las décadas de 1870 y 1890 se manifestó, por un lado, una apertura a la hora de evaluar las tradiciones y las novedades literarias españolas en la que algunos intelectuales argentinos oficiaron como articuladores entre dos mundos, como muestran los juicios de Vicente Quesada y Calixto Oyuela; $\mathrm{y}$, por otro, se dio paso a gestos conciliadores y de afinidad propiciados por los vínculos personales entre letrados de ambos territorios. La convivencia en espacios provistos por la diplomacia argentina y en los cenáculos intelectuales de Madrid parece haber propiciado el estrechamiento de vínculos que habilitó el paso de un rechazo monolítico a una recuperación selectiva de las tradiciones intelectuales españolas, como lo muestran las acciones y obras de Martín García Mérou y Santiago Estrada. A la vez, se perfiló con claridad la idea de la posibilidad concreta de dar forma a una comunidad intelectual basada en el idioma común.

\footnotetext{
50 Puede verse al respecto Bernabeu Albert, 1987.

51 Thiesse, 2010, p. 65.

52 Pueden verse detalles sobre estos contextos en Bruno 2018b.
} 
Los sucesos que se desenvolvieron en torno a los festejos y celebraciones del IV Centenario permiten pensar de qué manera ciertas expectativas surgidas desde espacios de sociabilidad e instituciones españolas podían generar tensiones en los letrados argentinos, siendo las reacciones de Miguel Cané y varios de sus contemporáneos frente a la Real Academia Española ilustrativas de esta tendencia. En cambio, la idea de una identidad común que hermanara en sus dinámicas a España y los países de América Latina vía los vínculos entre intelectuales decantaba paulatinamente.

\section{8: España, «la Hija de Roma, la Hermana de Francia, la Madre de América» ${ }^{33}$}

En 1889, mientras se realizaba la mencionada I Conferencia Panamericana, el cubano José Martí, en tanto observador y corresponsal de la misma para varios periódicos americanos, alertaba sobre la intención expansionista de Estados Unidos sobre el resto del continente: «de la tiranía de España supo salvarse la América española; y ahora, después de ver con ojos judiciales los antecedentes, causas y factores del convite, urge decir, porque es la verdad, que ha llegado para América española la hora de su segunda independencia» ${ }^{54}$.

Pero si esta sentencia parecía condenar el rol de España asociándola a la noción de tiranía - recuérdese que Cuba era aun en este contexto dominio español - y se hacía eco de las observaciones de letrados de los años postrevolucionarios, casi una década más tarde ${ }^{55}$, los acontecimientos bélicos de 1898 oficiaron como un momento intenso de reconsideraciones y balances respecto de España y su influencia en el continente americano, sobre todo como potencial contrapeso del avance norteamericano ${ }^{56}$.

La aparición en escena de Estados Unidos como nación expansionista generó un repertorio de representaciones destinadas a perdurar; por ejemplo, el mundo yankee comenzó a ser caracterizado como expresión su-

${ }^{53}$ La expresión pertenece a Rubén Darío y la referencia textual se indica en esta sección.

${ }_{54}$ Martí, 2005, p. 57.

55 Díaz Quiñones, 2006.

56 Bruno, 2018b. 
prema de los vicios del materialismo de corte anglosajón, mientras que España devino baluarte último y absoluto de la latinidad.

En este clima, debe pensarse la movilización de intelectuales que tuvo lugar durante los sucesos de 1898 en Buenos Aires; varias acciones se desplegaron en el marco de la guerra, los residentes españoles realizaron suscripciones patrióticas para construir un buque de guerra, se organizaron espectáculos artísticos con el fin de recaudar fondos para la causa, y destacados personajes del mundo de las letras, participaron en ciclos de conferencias con seno en varias salas teatrales porteñas en apoyo de la causa española ${ }^{57}$.

Entre estos eventos se destaca el realizado el 2 de mayo de 1898 en el Teatro de La Victoria de Buenos Aires; se trataba de un acto patrocinado por el Club Español en el que distinguidos intelectuales de la época participaron como oradores: Roque Sáenz Peña, Paul Groussac y José Tarnassi. Mientras que el último presentó una oda al pueblo español y la guerra en forma de poema, Groussac y Roque Sáenz Peña retomaron en sus discursos distintos ángulos de observación para analizar la contienda entre Estados Unidos y España.

Roque Sáenz Peña revisó varios temas ligados a los principios del derecho internacional y asumió el tono de fuerte opositor a Estados Unidos y sus proyectos expansionistas ${ }^{58}$; al final de su exposición destacaba ante un público predominante de inmigrantes españoles afincados en Argentina, la existencia de un vínculo indisoluble entre España y las naciones latinoamericanas:

«comparto vuestros anhelos y vuestras incertidumbres, y los comparto como hijo de una nación latinoamericana, que presiente para el porvenir, idénticos peligros a los que pesan sobre la madre patria. Tengo el sentimiento y el amor de mi raza; quiero y respeto como propias, sus glorias en la guerra y sus nobles conquistas en la paz. Naciones nuevas, sin tradición remota, pero con horizontes despejados y grandes, somos vástagos cercanos del árbol secular que derramó por el mundo su sombra generosa, a la que hoy devolvemos frutos maduros de admiración y de cariño» ${ }^{59}$.

57 García Sebastiani, 2013; García, 2000.

58 Roque Sáenz Peña fue representante argentino en la I Conferencia Panamericana realizada entre 1889 y 1890 en la ciudad de Washington y había planteado sus desacuerdos y resistencias ante el avance norteamericano.

59 Roque Sáenz Peña, 1898, p. 26. 
Paul Groussac, por su parte, en el mismo acto, describió los sucesos de 1898 como una «crisis suprema de la civilización». Su visión fue expresada por medio de imágenes contrapuestas de los distintos actores del enfrenamiento. Desde su perspectiva, las fuerzas que subyacían al conflicto podían sintetizarse en un par de opuestos bien definido: «latinidad», por un lado, y «yanquismo», por otro.

Respecto de España, destacaba los valores positivos de su historia y de su cultura al poner de relieve su rol civilizatorio: «ha realizado a su turno un ideal humano de valor, de nobleza, de altivez caballeresca, de exaltado y místico espiritualismo» ${ }^{60}$. En paralelo, criticaba varios rasgos de Estados Unidos: su grandeza material y grotesca y la falta de educación de sus habitantes, entre otros aspectos. Imágenes que se condensan en la figura del Calibán identificada con el país del Norte ${ }^{61}$.

Luego del discurso de Groussac, el repertorio de dicotomías interpretativas propuestas en torno al conflicto bélico de 1898, entre las que se destacan yankismo/latinidad, bárbaros/civilizados, materialismo/espiritualismo, advenedizos/baluartes de la tradición, cultura/naturaleza, fueron retomadas en un artículo de Rubén Darío titulado «El triunfo de Calibán». En el mismo, reproducido en distintos periódicos de habla hispana, se canalizaron contundentes declaraciones del poeta nicaragüense. Por un lado, destacaba sobre Estados Unidos:

«Y los he visto a esos yankees, en sus abrumadoras ciudades de hierro y piedra y las horas que entre ellos he vivido las he pasado con una vaga angustia. Parecíame sentir la opresión de una montaña, sentía respirar en un país de cíclopes, comedores de carne cruda, herreros bestiales, habitadores de casas de mastodontes. Colorados, pesados, groseros, van por sus calles empujándose y rozándose animalmente, a la caza del dollar. El ideal de esos calibanes está circunscripto a la bolsa y a la fábrica».

Por otro, refiriéndose a España, el poeta nicaragüense declamaba:

«España no es el fanático curial, ni el pedantón, ni el dómine infeliz, desdeñoso de la América que no conoce; la España que yo defiendo se llama Hidalguía, Ideal, Nobleza; se llama Cervantes, Quevedo, Gón-

60 Groussac, 1898, pp. 43 y 44.

61 Fernández Retamar, 2000a. 
gora, Gracián, Velázquez; se llama el Cid, Loyola, Isabel; se llama la Hija de Roma, la Hermana de Francia, la Madre de América» ${ }^{62}$.

En pocas palabras, en el contexto de 1898, varios intelectuales optaron por recuperar la figura de España, defenestrada durante décadas y reivindicada parcialmente desde 1870 , como se ha visto, apelando a los rasgos positivos de su historia y su cultura, a la vez que ponían de relieve su misión civilizatoria durante los procesos de conquista y de colonización. La antaño metrópoli ibérica podía, a la luz de la guerra, ser celebrada en tanto portadora de supremos ideales: nobleza, valor, hidalguía y espiritualismo. Quedaba así esbozado un repertorio que se retomaría ampliamente a la hora de pensar España como baluarte de la latinidad y eslabón necesario entre las nuevas naciones latinoamericanas surgidas de las rupturas de los lazos coloniales acaecidos entre 1810 y 1824 y un pasado común ${ }^{63}$.

El momento 1898, entonces, fue el de mayor efervescencia en lo referido a las reivindicaciones de España por intelectuales que tuvieron gravitación en Argentina. La recuperación de los valores hispánicos, que por décadas habían sido rechazados, combatidos, o recuperados selectivamente, devino una garantía de la latinidad - entendida en términos amplios como una identidad de la Europa occidental-, como sintetizó de manera contundente Paul Groussac.

En suma, la situación internacional configurada en torno a la guerra no fue percibida solamente en términos de conflicto geopolítico y económico, sino también como una batalla entre principios culturales contrapuestos de incierto desenlace. En este marco, los tópicos dilectos de Domingo Faustino Sarmiento y Esteban Echeverría sobre el atraso y la decadencia fueron suspendidos para dar paso a la interpretación de España como faro de la civilización occidental en el marco de los repertorios propuestos por varios intelectuales latinoamericanos. Fue también entonces cuando numerosos letrados comenzaron a pensar la nación española desde un lugar que tomaba distancia de las lecturas más extendidas en el siglo XIX: ya no ponderaban a sus países como excolonias, sino como incipientes naciones que podían relacionarse en pie de igualdad con

62 Darío, 1898.

${ }^{63}$ Sobre las ideas de latinidad y las tensiones al respecto entre España, Francia y América Latina pueden verse, entre otros, Fernández Retamar, 2000b; Niño Rodríguez, 1992, y Terán, 1986. También pueden consultarse las distintas perspectivas recogidas en Díaz Ruíz, 2000. 
España para afirmar, en este nuevo contexto, la anhelada unidad hispanoamericana por la que habían bregado insignes representantes de ambos continentes ${ }^{64}$. En este punto, las opciones propuestas fueron varias. Mientras que algunos intelectuales optaron por depositar en la raza las esperanzas de hermanamiento - como sugería tímidamente Roque Sáenz Peña en el Teatro de la Victoria-, otros bregaron por la noción de idioma como el principal lazo de unidad - como manifestaron Eduardo Wilde y Miguel Cané- ${ }^{65}$. De este modo, de manera algo paradójica, la derrota de España es lo que generó una coyuntura de recuperación más certera y densa a la hora de organizar repertorios de imágenes destinadas a perdurar, como los que cristalizaron en la voz de Paul Groussac y la pluma de Rubén Darío.

\section{Giro del siglo XIX al Xx: España, «un país contradictorio, de espíritu incierto» ${ }^{66}$}

El momento 1898 había generado entusiasmo en las evaluaciones sobre España como «madre patria» de las nuevas naciones del continente americano que observaban con desconfianza las intenciones expansionistas estadounidenses. Pasado el conflicto bélico, y ya en el giro de siglo, las variantes interpretativas de figuras de la vida letrada argentina sobre la Península Ibérica y sus tradiciones intelectuales presentaron nuevas modulaciones.

En este sentido, las observaciones de Groussac revisten un interés singular porque, además de ser una voz central en la articulación del repertorio asociado con 1898 en clave de antiimperialismo, recorrió España en el contexto mismo de desenvolvimiento de la guerra. Los énfasis de su tono se vieron moderados al recorrer territorio español. Su visita estuvo acompasada por la intención de responder al siguiente interrogante: «¿cómo ha repercutido en el alma española el tremendo descalabro que probablemente señala una nueva era en su historia - la era inaudita y nunca prevista, para la gran navegante y colonizadora de otros siglos, en que sale del campo de batalla mutilada y empobrecida, una España ya sin marina ni colonias?» ${ }^{67}$.

\footnotetext{
64 Barriuso, 2009.

65 Bruno, 2018b.

${ }^{66}$ La expresión pertenece a Manuel Ugarte y la referencia textual se indica en esta sección.

67 Groussac, 1904, p. 114.
} 
Guiado por esta inquietud rectora, Groussac observaba que las repercusiones sociales de la guerra no eran tan drásticas como esperaba. En este sentido, se refería severamente a la sociedad de la capital y a la «frivolidad madrileña»; rasgo que subrayó luego de constatar que la prensa cubría casi con la misma intensidad los sucesos de Cuba y Filipinas y «las hazañas tauromáquicas de Pailla y Quintio» ${ }^{68}$. A partir de estas consideraciones, el viajero recurrió a la estrategia propuesta por Sarmiento, la de observar las corridas de toros como maqueta de la sociedad española y dar así cuenta de las facetas de «inferioridad científica e industrial, odio al trabajo y al esfuerzo» ${ }^{69}$.

Pero pese a esta tentación interpretativa, sus opiniones se sofrenaron luego de entrevistarse con varias figuras de la vida cultural española. Su balance fue, entonces, el siguiente: «debajo de la envoltura frívola, la herida profunda gotea sangre. Y esto lo siento muy vivo y real al conversar con espíritus elevados como Azcárate y Silvela o literatos observadores como Pérez Galdós o Menéndez Pidal» ${ }^{70}$. Fue el intercambio con estos hombres de letras lo que lo impulsó a reflexionar sobre las opciones de que se abriera una nueva era histórica en España, en las que sus habitantes se concientizaran de la necesidad de aunar esfuerzos y realizar una autocrítica; en este sentido, y sin abandonar los juicios severos sobre la sociedad, Groussac apuntaba:

«Sería preciso convencer al pueblo español de que los desastres nacionales, cuando ocurren tan inevitables y previstos, no son culpa de Cervera, ni de Sagasta, ni de Cánovas, sino la consecuencia lógica de una larga inferioridad científica e industrial debida por entero a un absurdo concepto de vida moderna; al odio al trabajo y al esfuerzo, al desdén de la lucha pacífica que arma para la otra: a la contemplación infatuada y pueril de un pasado irrevocablemente muerto y que, en esa forma anticuada al menos, no puede ya resucitar» ${ }^{71}$.

De este modo, las observaciones categóricas del Teatro de la Victoria de mayo se vieron un tanto matizadas en las reflexiones suscitadas por el viaje realizado apenas dos meses después, en julio de 1898. Luego de la

\footnotetext{
68 Groussac, 1904, p. 119.

69 Groussac, 1904, p. 119.

70 Groussac, 1904, pp. 116 y 117.

71 Groussac, 1904, p. 119 y 120.
} 
declamación sobre la necesidad de recuperar la herencia hispana sin fisuras, Groussac y otros intelectuales postularon juicios menos categóricos y más ajustados a los que observaban en sus viajes.

Así lo constatan las observaciones de otra de las voces centrales de 1898, Rubén Darío. Apenas un año después de la guerra viajó a Madrid y al llegar a la ciudad advirtió «el mismo ambiente ciudadano de siempre», pese a ello se percibía que: «acaba de suceder el más espantoso de los desastres; pocos días han pasado desde que en París se firmó el tratado humillante en que la mandíbula del yankee quedó por el momento satisfecha después del bocado estupendo» ${ }^{72}$. Los acuerdos de paz daban paso, para Darío, a nuevas preguntas sobre qué podía esperarse de España como articuladora de una república de las letras hispanoamericana.

Los juicios iniciales no fueron prometedores, percibía «en la atmósfera una exhalación de organismo descompuesto»; el poeta vaticinaba el fin de una época, y, en sintonía con la búsqueda de interlocutores y referentes del mundo letrado que había ya juzgado imperiosa Groussac, destacaba: «he buscado en el horizonte español las cimas que dejara, no hace mucho tiempo, en todas las manifestaciones del alma nacional: Cánovas muerto; Ruiz Zorrilla muerto; Castelar desilusionado y enfermo; Valera ciego; Campoamor mudo; Menéndez y Pelayo... No está por cierto España para literaturas, amputada, doliente, vencida $>^{73}$.

Pero, a la vez que las condiciones de la vida letrada española le resultaban desoladoras, Darío celebraba que en las excolonias «por obra de nuestro cosmopolitismo y, digámoslo, por la audacia de los que hemos perseverado, se ha logrado en el pensamiento de América una transformación que ha producido, entre mucha broza, verdaderos oros finos, y la senda está abierta ${ }^{74}$. Se invertía en estos juicios la mirada unidireccional de los intelectuales latinoamericanos de vindicar - o rechazar - referencias españolas y se recortaba una nueva chance: la de asumir que en los territorios americanos se hallaban las simientes para dar nuevos bríos a España. Como algunos aportes bibliográficos han señalado, desde las miradas de diferentes intelectuales latinoamericanos las antaño colonias parecían ofrecer ahora una serie de novedades - siendo el modernismo el rótulo que se utiliza para sintetizar varias de ellas - que eran vistas con beneplácito ${ }^{75}$.

\footnotetext{
72 Darío, 1907, p. 22.

73 Groussac, 1904, p. 112.

74 Darío, 1907, p. 26.

75 Zuleta, 1988; Morillas Ventura, 2002.
} 
Con estos acentos, Darío manifestaba optimismo en la comunidad de escritores y artistas para propiciar intercambios y reforzar los lazos de afinidad. Señalaba en esta dirección que, si bien hasta el momento en las «relaciones intelectuales ha habido siempre un desconocimiento desastroso» ${ }^{76}$, se iniciaba ahora una etapa de vinculaciones «más provechosas, duraderas y fundamentales que las mutuas zalemas pasadas de un iberoamericanismo de miembros correspondientes de la Academia» ${ }^{77}$.

$\mathrm{Al}$ calor de estos balances y otros afines, figuras intelectuales que reforzaron su protagonismo en las cartografías iberoamericanas a lo largo de los primeros años del siglo Xx, propusieron nuevas reflexiones sobre España. De este modo, si Groussac y Darío habilitaron la posibilidad de pensar los momentos inmediatamente posteriores a 1898, ya entrado el nuevo siglo se postularon otras tendencias interpretativas. Entre ellas, son dos las que tuvieron mayor presencia.

La primera, proponía, en cierto sentido, regresar a la grilla ofrecida por los padres fundadores de la vida intelectual argentina y rechazar a España de una manera tajante, dado que, en el marco del escenario internacional, estaba incluso más debilitada por la pérdida de sus últimas colonias en 1898. Dentro de esta tendencia, es ilustrativa la voz de José Ingenieros, quien, en sus crónicas de viaje iniciadas en 1905, señalaba los hitos de la grandeza del arte español como el único elemento reivindicable de la tradición ibérica: «España puede consolarse de la pérdida de otras glorias pensando que sus pintores dominan en todas partes; la herencia de Velázquez y del Greco, de Goya y de Ribera, se conserva abundante, prestigiosa» ${ }^{78}$. Y, en simultáneo, no dudaba en describir las corridas de toros como un espectáculo semi-bárbaro, al que denominaba «la morfina de España»; desde su perspectiva, el mismo dejaba en evidencia: «la encarnación de todas las pasiones, ceguera de todos los ideales, inconciencia de todos los ensueños» ${ }^{79}$. En la mirada de Ingenieros, las tentaciones de obtener conclusiones sociológicas de las corridas asumían, una vez más, centralidad. Destacaba, de este modo, que la actitud general de la sociedad española - tomando la población de Madrid como foco de obser-

\footnotetext{
76 Groussac, 1904, p. 120.

77 Groussac, 1904, p. 118.

78 Ingenieros, 1957, p. 77.

79 Ingenieros, 1957, p. 127.
} 
vación - se podía describir con las siguientes palabras, que le atribuía al escritor español Eusebio Blasco: una sociedad dispuesta a «todo, menos trabajar» ${ }^{80}$.

Aunque alejadas de las observaciones de Rubén Darío, hay un punto de coincidencia entre ambos. Dado que, en su diagnóstico, Ingenieros consideraba que, lejos de las prácticas atávicas que observaba en España: «los pueblos jóvenes y fecundos no necesitan morfina» ${ }^{81}$. Una vez más, se afirmaba aquí, que las naciones americanas podían dar algunas lecciones a la antaño metrópoli.

Lejos de las consideraciones de Ingenieros, propensas a restituir las miradas dominantes de los primeros tres cuartos del siglo XIX, una segunda tendencia emergente se dibujó a inicios de la nueva centuria. La misma fue encarnada, sobre todo, por figuras que se percibían como portadoras de los mentados bríos latinoamericanos y se ponían al servicio de la causa del estrechamiento de vínculos para conformar una comunidad intelectual hispanoamericana. La voz que articuló más acabadamente esta tendencia es la de Manuel Ugarte. Ya en sus Crónicas de Boulevard de 1903 - se trata de una serie de relatos sobre una estadía en Francia - , a la hora de reflexionar sobre la Península Ibérica, la imagen de las dos Españas se esbozaba con claridad ${ }^{82}$ :

«Hay dos Españas: la Antigua, que perpetúa la tradición de los reyes católicos y vive todavía en el siglo XVIII; y la Moderna, llena de vigores y savia regeneradora. La primera, que despierta el recuerdo de pasadas luchas y viejas aberraciones, nos es, naturalmente, menos simpática que la segunda, que tiene nuestro espíritu y aspira como nosotros a la verdad y a la luz. Esas dos naciones delimitadas dentro de nación están en guerra constante, y aprovechan el menor pretexto para reanudar sus luchas. Son dos campos completamente separados, dos mentalidades absolutamente diferentes, que difícilmente podrán fundirse en una fórmula común ${ }^{83}$.

${ }^{80}$ Ingenieros, 1957, pp. 176 y 177.

81 Ingenieros, 1957, p. 127.

${ }^{82}$ La imagen de las dos Españas ha sido ampliamente trabajada en la historiografía española. Como referencia general puede consultarse Álvarez Junco, 2002, pp. 383-431. Se usa aquí de una manera descriptiva para dar cuenta de las miradas propuestas por Manuel Ugarte en los años iniciales del siglo Xx, y sin intenciones de simplificar un tema en debate y complejo.

83 Ugarte, 1903, p. 234. 
Era en la segunda España, aquella tras la verdad y la luz, donde Ugarte encontraba nuevas circunstancias para revivir la idea de la comunidad intelectual hispanoamericana. Estas impresiones pueden verse de manera más acabada en su libro Visiones de España, publicado en 1904, que compila las impresiones sobre sus viajes por territorios peninsulares. Allí da cuenta, una vez más, de las «dos Iberias»: «la del pasado, la de las cabalgatas de triunfo y los gestos heroicos, la que fue emperatriz y guía: y la del presente, trabajada por desmoronamientos graves que esfuerzo colectivo podrá impedir» ${ }^{84}$. Pero no es en los esfuerzos sociales colectivos donde Ugarte encontró las potencialidades para redimir España; confiaba, en cambio, en la clave propuesta ya por Rubén Darío: la vinculación entre figuras de la vida intelectual latinoamericana y española como usina generadora de un futuro común. Las miradas dejaban de estar posadas en el pasado y se centraban ahora en el porvenir de una comunidad letrada.

De hecho, en las crónicas sobre su travesía, Ugarte propuso una nueva forma de recorrer España. Devino pionero en armar el índice de su libro de crónicas de viaje dando cuenta de sus impresiones sobre figuras del espacio intelectual de los destinos que visitaba. Mientras que en los relatos de travesías de las décadas anteriores los encuentros con literatos españoles eran referidos al pasar o con referencias aleatorias - en contraste, es usual encontrar testimonios de entrevistas con escritores franceses, visitas a las discusiones parlamentarias en Inglaterra, y conferencias en universidades de distintos países europeos -, el libro de Ugarte inauguró un recorrido de estaciones eslabonados por nombres propios: Benito Pérez Galdós, Juan Valera, Vicente Blasco Ibáñez, Salvador Rueda y Vicente Medina son, a la vez, figuras de la vida intelectual española y secciones de su libro.

Esta decisión de escritura marca un punto de ruptura: en Madrid, Ugarte se alejó de los recorridos sugeridos por las guías que la mayoría de los letrados latinoamericanos seguían al viajar por Europa - entre las que se destacan las de la firma editorial Baedeker- y eligió, en cambio, conocer redacciones de periódicos y casas editoriales, visitar estudios de escritores y artistas, concurrir a funciones teatrales para entablar conversaciones en los intervalos. Y fue, justamente, en estos espacios de sociabilidad y camaradería - muy diferentes a las corridas de toros - en los que

${ }^{84}$ Ugarte, 1904, p. 11. 
Ugarte halló lo que definió en sus crónicas como la «vida moderna» de España.

En la descripción de una galería de celebridades literarias encontraba, además, pistas sobre lo que estaba por fenecer - lo castizo, el encierro, la reticencia a Francia-, y lo que consideraba parte de un renacimiento: «lo que perseguimos en América; la concisión del estilo, la exactitud del color, la precisión, la sencillez y la verdad» ${ }^{85}$. España aparecía ante sus ojos como una tierra que ahora podía satisfacer las demandas intelectuales de los países latinoamericanos ${ }^{86}$.

Ugarte reafirmó esta observación al narrar encuentros entre letrados españoles y argentinos; en los mismos, subrayaba, se habían dejado atrás los acaloramientos y tensiones de antaño y se daban discusiones de interés común. En su libro, narra con soltura su coincidencia en un intervalo teatral con Núñez de Arce, o el hecho de estar sentado al lado de Ramón del Valle Inclán en una función; en estas y otras ocasiones, las conversaciones parecían fluir entre hombres que convivían en armonía en una comunidad intelectual. En dirección complementaria, al visitar a Juan Valera, destacaba: «conversamos de la lengua española, del francesismo, de la Academia, de las libertades de lenguaje que nos tomamos en América, y el viejo conservador de las letras, el legendario cancerbero del estilo, no me pareció tan intratable como algunos se complacen en afirmar» ${ }^{87}$. Ante el gesto de apertura de Valera al conversar sobre el idioma, Ugarte detectaba que había quedado atrás el momento en el que «la atmósfera de la lengua castellana ha(bía) acabado por hacerse irrespirable». Atribuía esta nueva situación, entre otros motivos, a la publicación de un texto de Miguel de Unamuno en La España Moderna, el artículo «Contra el purismo» ${ }^{88}$, que habilitó un diálogo fluido entre intelectuales americanos y españoles ${ }^{89}$. Por su parte, detectó un interés de estos últimos en los pensadores de América Latina, en conversación con Salvador Rueda, le resultó especialmente interesante que le formulara «mil preguntas sobre la vida intelectual sur-americana» ${ }^{90}$.

\footnotetext{
85 Ugarte, 1904, p. 106.

86 Ugarte, 1904, p. 101.

87 Ugarte, 1904, p. 103.

88 Unamuno, 1903.

89 Sepúlveda Muñoz, 2005, p. 217.

90 Ugarte, 1904, p. 111.
} 
En todos estos indicios que le ofrecían sus conversaciones con intelectuales españoles, en la vitalidad de las ideas y las dinámicas culturales de Madrid, y en la curiosidad que varios interlocutores le manifestaban sobre el pensamiento latinoamericano, Ugarte encontró motivos para manifestar entusiasmo frente a España y sus tensiones sin caer en la tentación de los tópicos de la hispanofobia:

«España es un país contradictorio, de espíritu incierto, donde se entrechocan muchos antagonismos y se mezclan muchas cosas. Los que se la imaginan en el extranjero como un torreón medioeval, cerrado a todas las manifestaciones del alma moderna, caen en un error lamentable» ${ }^{91}$.

Parecía, de este modo, quedar superada la imagen de España como la nación más rezagada de Europa y se abrían nuevas posibilidades para un diálogo entre referentes intelectuales de Iberoamérica.

En suma, hacia el giro de siglo se desplegaron reflexiones sobre las dinámicas en tensión dentro de España, por un lado, y sobre las potencialidades que tenían para ofrecer las nuevas naciones, por otro. Se recortó así, con notable nitidez, un tópico bastante extendido en la primera década del siglo XX en los dos lados del Atlántico: el de las potencialidades de la América Latina en tanto dadora de una nueva savia para la regeneración de España ${ }^{92}$. Si Rubén Darío había abierto esta senda, la misma fue recorrida de manera más categórica por Manuel Ugarte. De este modo, pese a que se manifestaron voces que caían en la tentación de abrevar en las impresiones de las primeras décadas del siglo XIX - como la de José Ingenieros - , las lecturas más articuladas se inscribían en estas nuevas modulaciones. Como ejemplarmente narró Ugarte en su libro, las sociabilidades comunes, la fluidez en el trato interpares, y la curiosidad que algunos intelectuales españoles mostraban en estos años respecto de los países latinoamericanos dan cuenta de la efectividad de los vínculos tendidos horizontalmente entre hombres de letras. Lejos había quedado para estos años aquella sorpresa que expresó Miguel Cané a mediados de 1880 al sentirse interpelado por el presidente del Ateneo de Madrid.

\footnotetext{
91 Ugarte, 1904, p. 139.

92 Niño Rodríguez, 1992 y Moreno Luzón, 2010.
} 


\section{Consideraciones finales}

En este artículo se revisaron distintas estaciones cronológicas con el objetivo de dar cuenta de las miradas que intelectuales argentinos ofrecieron en el largo plazo sobre España y las posibilidades de que sus figuras $\mathrm{y}$ tradiciones intelectuales tuvieran lugar en una comunidad letrada hispanoamericana. Las voces predominantes de las primeras décadas postrevolucionarias partían de un diagnóstico negativo de España y sus tradiciones intelectuales para dar cuenta de la necesidad imperiosa de emancipar el pensamiento de las nuevas naciones americanas. Sin embargo, con el correr de las décadas, se perfiló un repertorio de impresiones e imágenes que permiten sugerir que las intenciones sintetizadas en la idea de comunidad hispanoamericana de letrados se fueron definiendo de manera paulatina. La misma se planteaba como un entramado de relaciones personales entre intelectuales con formas de comunicación e intercambio horizontal donde primaban algunas características del «cosmopolitismo intelectual» típico de una república de las letras. Esta idea parecía ser productiva, como lo constatan las apreciaciones de Eduardo Wilde, por ejemplo, pero también algunos emprendimientos de sociabilidad; en cambio, si se impulsaba desde iniciativas institucionales, o «logísticas estatales», podía generar resistencias, como demuestran las numerosas reacciones frente a la Real Academia Española, entre las que se cuentan las de Cané y Lució V. López, entre tantas otras ${ }^{93}$.

A su vez, se pueden ponderar algunos de los efectos de las intenciones surgidas a la luz de la noción de una comunidad más allá de las fronteras surgida en estos años. Respecto de la oportunidad de establecer lazos de fraternidad en base a la lengua, son elocuentes las opiniones expresadas en una polémica sobre el origen y la validez del idioma utilizado por los argentinos que se dio en torno a 1900. En ese contexto se definieron dos tendencias claras: aquella de quienes sostenían fervorosamente que el idioma de esas tierras era tributario y continuador del de España; y otra de quienes afirmaban que debía bregarse por la emancipación lingüística por medio de la configuración de un idioma radicalmente diferente. En el marco de este debate, las figuras que aquí relevamos, como Miguel Cané y Eduardo Wilde, no titubearon a la hora de hacer una defensa tajante del español como idioma oficial y único de los habitantes de la nación argen-

93 Las dos expresiones entrecomilladas se encuentran en Thiesse, 2010, pp. 64 y 65. 
tina. Esta discusión da indicios para sostener que el rechazo sistemático a España y sus herencias era un tópico que para 1900, guerra de 1898 de por medio, ya no contaba con apoyo extendido ${ }^{94}$.

Complementariamente, puede argumentarse que la imagen idílica de una comunidad intelectual de corte hispanoamericano en la que pudieran interactuar latinoamericanos y españoles que se delineó hacia la década de 1880 tomó forma más acabada en los años finales de la década de 1890, como ha mostrado extendidamente la bibliografía que estudió los vínculos y circulaciones propiciadas por las distintas manifestaciones agrupadas bajo el rótulo de modernismo ${ }^{95}$, y gracias a los desplazamientos y la presencia de distintos intelectuales en destinos cruzados entre España, Argentina y otras latitudes americanas, siendo casos como el de José Martí o Rubén Darío los más mencionados ${ }^{96}$. Pero, a su vez, los procesos aquí relevados aportan información relevante para pensar en el entramado en el que surgieron repertorios de ideas en estas décadas que luego tendrían expresiones más acabadas en el marco de los festejos del Centenario de la revolución, celebrado en Argentina en 1910. En ese contexto, las visitas de intelectuales españoles a Argentina - entre los que se cuentan Rafael Altamira, Ramón del Valle Inclán, Adolfo Posada, Vicente Blasco Ibáñez, y otros-, por ejemplo, mostraba hasta qué punto se contaba ya con un territorio abierto a la hora de establecer vínculos entre figuras de ambas naciones que son estudiadas hoy a la luz de rótulos como hispanoamericanismo, americanismo, iberoamericanismo, entre otras opciones ${ }^{97}$.

Otro elemento que puede verse a la luz de las voces aquí relevadas es cómo junto con los entramados de relaciones que generaron instituciones y asociaciones étnicas, se dibujaban también posibilidades para que letrados argentinos se comprometieran y solidarizaran con causas españolas - como muestran ejemplarmente los eventos que aquí se reseñaron del Teatro de la Victoria en $1898-$. En este sentido, como varios autores han señalado, la presencia de una considerable cantidad de inmigrantes españoles en territorio argentino generó un clima de opinión más favorable a la hora de evaluar el rol de España ${ }^{98}$. A la vez, los escenarios propiciados por los viajes y las estadías de intelectuales argentinos en la

\footnotetext{
94 AA.VV., 1983.

95 Zuleta, 1988; Fogelquist, 1968.

96 Ramos, 2001.

97 Niño Rodríguez, 1992 y Dalla Corte y Prado, 2006.

${ }_{98}$ Entre otras contribuciones, pueden verse las referencias de la nota 6 de este artículo.
} 
Península Ibérica dieron pie a un estrechamiento de vínculos y un reconocimiento de afinidades.

Cabe observar que la convivencia posible en una república de las letras hispanoamericana parecía más factible en un contexto en que dentro de Argentina se estaba conformando una identidad nacional ${ }^{99}$. Este hecho habilita algunas reflexiones sobre las tensiones que podían generarse entre las identidades nacionales de cada una de las naciones latinoamericanas, el latinoamericanismo como identidad regional - surgido a fines del siglo XIX - y el hispanoamericanismo como proyecto identitario. De hecho, las voces aquí relevadas pertenecen a intelectuales que difícilmente encajan en las caracterizaciones de aquellas figuras públicas que pensaron e inventaron la nación de manera sistemática. En este sentido, este trabajo es una invitación a pensar los procesos de construcción de repertorios identitarios en clave transnacional, en sintonía con algunas líneas de la historiografía en la última década ${ }^{100}$.

\section{Fuentes}

AA.VV., España y Estados Unidos. Función dada en el Teatro de la Victoria el 2 de mayo de 1898 bajo el patrocinio del Club Español de Buenos Aires, a beneficio de la Suscripción Nacional Española. Conferencias de los Señores Dr. Roque Sáenz Peña, Paul Groussac y Dr. José Tarnassi. Prólogo del Dr. Severiano Llorente, Compañía General de Billetes de Banco, Buenos Aires, 1898.

AA.VV., En torno al criollismo. Textos y polémica (antología a cargo de Alfredo Rubione), Centro Editor de América Latina, Buenos Aires, 1983.

ALBERDI, Juan Bautista, Fragmento preliminar al estudio del Derecho, volumen 2, Imprenta de la Libertad, Buenos Aires, 1837.

CANÉ, Miguel, Prosa ligera, Casa Vaccaro, Buenos Aires, 1919.

DARÍO, Rubén, «El triunfo del Calibán» en El cojo ilustrado, 20 de mayo de 1898. Consultado en línea: https://www.ensayistas.org/antologia/XIXA/ dario/. Consultado el 20/06/2019.

DARÍO, Rubén, Autobiografías (Prólogo de Enrique Anderson Imbert), Marymar, Buenos Aires, 1976.

DARÍO, Rubén, España contemporánea, Garnier Hermanos, París, 1907.

99 Bertoni, 2001.

100 Núñez Seixas, 2017; Garner y Smith, 2017. 
ECHEVERRIA, Esteban, Obras completas. Editadas por Juan María Gutiérrez, tomo V, Carlos Casavalle Editor, Buenos Aires, 1874.

ESTRADA, Santiago, Rafael Calvo y su repertorio, M. Biedma, Buenos Aires, 1883.

GARCÍA MÉROU, Martín, Ley social, Félix Lajoaune, Buenos Aires, 1885.

GROUSSAC, Paul, «José de Espronceda», en Revista Arjentina, tomo X, Buenos Aires, 1871, pp. 123-167.

GROUSSAC, Paul, El viaje intelectual. Impresiones de naturaleza y arte. Primera Serie, Librería General de Victoriano Suárez, Madrid, 1904.

INGENIEROS, José, Crónicas de viaje, 1905-1907, Elmer Editor, Buenos Aires, 1957.

LÓPEZ, Lucio V., Recuerdos de viaje, Alfredo Rosso, Buenos Aires, 1915.

MARTÍ, José, Nuestra América, con prólogo y cronología de Juan Marinello, Caracas, Biblioteca Ayacucho, 2005 p. 57.

OYUELA, Calixto, «Poesías de Andrés Bello», Nueva Revista de Buenos Aires, año 2, tomo V, 1882, pp. 549-566.

QUESADA, Vicente, «Revista Bibliográfica», Nueva Revista de Buenos Aires, año 1, tomo I, 1881, pp. 659-677.

SARMIENTO, Domingo Faustino, Viajes por Europa, África y América, 18451847, Buenos Aires, Fondo de Cultura Económica, 1993.

UGARTE, Manuel, Crónicas del bulevar, Garnier Hermanos, París, 1903.

UGARTE, Manuel, Visiones de España (Apuntes de un viajero argentino), F. Sempere y C. Editores, Valencia, 1904.

WILDE, Eduardo, Viajes y observaciones. Cartas a «La Prensa». Inéditas, tomo II, Martín Biedma, Buenos Aires, 1892.

\section{Bibliografía}

ALFÓN SCAFATI, Fernando, «Los orígenes de las querellas sobre la lengua en Argentina», en Horacio González, Beligerancia de los idiomas. Un siglo y medio de discusión sobre la lengua latinoamericana, Colihue, Buenos Aires, 2008, pp. 43-77.

ÁLVAREZ JUNCO, José, Mater Dolorosa. La idea de España en el siglo XIX, Taurus, Madrid, 2001.

ARRIETA, Rafael, La literatura argentina y sus vínculos con España, Institución cultural española, Buenos Aires, 1948.

BARRIUSO, Carlos, Los discursos de la modernidad: nación, imperio y estética en el fin de siglo español (1895-1924), Biblioteca Nueva, Madrid, 2009.

BERNABEU ALBERT, Salvador, 1892: El IV Centenario del descubrimiento de América en España: coyuntura y conmemoraciones, Consejo Superior de Investigaciones Científicas, Madrid, 1987. 
España como caleidoscopio. Observaciones de intelectuales argentinos...

BERNASCONI, Alicia y FRID, Carina (eds.), De Europa a las Américas. Dirigentes y liderazgos (1880-1960), Buenos Aires, Biblos, 2006.

BERTONI, Lilia Ana, Patriotas, cosmopolitas y nacionalistas. La construcción de la nacionalidad argentina a fines del siglo XIX, Fondo de Cultura Económica, Buenos Aires, 2001.

BRUNO, Paula, Martín García Mérou. Vida intelectual y diplomática en las Américas, Universidad Nacional de Quilmes, Bernal, 2018a.

BRUNO, Paula, «Un momento latinoamericano. Voces intelectuales entre la I Conferencia Panamericana y la Gran Guerra», en Ferran Archilés, y Maximiliano Fuentes (eds.), Ideas comprometidas. Los intelectuales y la política, Akal, Madrid, 2018b, pp. 57-77.

BRUNO, Paula, «Vida intelectual de la Argentina de fines del siglo XIX y comienzos del xx. Un balance historiográfico», PolHis. Revista Bibliográfica del Programa Interuniversitario de Historia Política, núm. 9, 2012, pp. 69-91.

CAGIAO VILA, Pilar y Jorge Enrique Elías-Caro, España como escenario. Política y acción cultual de diplomáticos latinoamericanos (1880-1936), Editorial UniMagdalena, Santa Marta, 2018.

COLOMBI, Beatriz, Viaje intelectual. Migraciones y desplazamientos en América Latina (1880-1915), Beatriz Viterbo Editora, Rosario, 2004.

DAHMEN, Wolfgang et al. (coordinadores), Lengua, historia e identidad/Sprache, Geschichteund Identität. Perspectiva española e hispanoamericanal Spanische undhispanoamerikanische Perspektiven, Gunter Narr Verlag, Tubinga, 2006.

DALLA CORTE CABALLERO, Gabriela y PRADO, Gustavo, «Luces y sombras de dos paradigmas del americanismo español en la renovación del diálogo hispanoamericano (1909-1912)», en Anuario de Estudios Americanos, vol. 63, 2, 2006, pp. 195-216.

DE ZULETA, Emilia, «El hispanismo de Hispanoamérica», Hispania, 75, 4, 1992, pp. 950-965.

DEVOTO, Fernando y PAGANO, Nora, Historia de la historiografía argentina, Editorial Sudamericana, Buenos Aires, 2009.

DEVOTO, Fernando y BARBERO, María Inés, Los nacionalistas (1910-1932), Centro Editor de América Latina, Buenos Aires, 1983.

DEVOTO, Fernando, Nacionalismo, fascismo y tradicionalismo en la Argentina moderna. Una historia, Siglo XXI Iberoamericana, Buenos Aires, 2002.

DÍAZ QUIÑONES, Arcadio, Sobre los principios. Los intelectuales caribeños y la tradición, Universidad Nacional de Quilmes, Bernal, 2006.

DÍAZ RUIZ, Ignacio (coordinador), Cultura en América Latina. Deslindes de fin de siglo, Universidad Nacional Autónoma de México, México, 2000.

FERNÁNDEZ RETAMAR, Roberto, Todo Calibán, Editorial Letras Cubanas, La Habana, 2000a. 
FERNÁNDEZ RETAMAR, Roberto, «América Latina y el trasfondo de Occidente», en Zea, Leopoldo (coord.), América Latina en sus ideas, Siglo XXI, México, 2000b, pp. 300-330.

FERNÁNDEZ, Alejandro y José Moya (eds.), La inmigración española en la Argentina, Biblos, Buenos Aires, 1999.

FIGALLO LASCANO, Beatriz, Argentina y España. Entre la pasión y el escepticismo, Teseo, Buenos Aires, 2014.

FOGELQUIST, Donald, Españoles de América y americanos de España, Gredos, Madrid, 1968.

GARCÍA, Ignacio «Apoyo a los españoles a la causa de la Cuba española. El caso argentino», Estudios Sociales, 19, 2000, pp. 85-104.

GARCÍA SEBASTIANI, Marcela (dir.), Patriotas entre naciones. Elites emigrantes españolas en Argentina (1870-1940), Editorial Universidad Complutense, Madrid, 2011.

GARCÍA SEBASTIANI, Marcela, «España fuera de España. El patriotismo español en la emigración argentina: una aproximación», Hispania, 73, 244, 2013, pp. 469-500.

GARNER, Paul y Ángel Smith, Nationalism and transnationalism in Spain and Latin America, 1808-1923, University of Wales Press, Cardiff, 2017.

HALPERIN DONGHI, Tulio, Reforma y disolución de los imperios ibéricos 1750-1850, Alianza Editorial, Madrid, 1985.

LOJO, María Rosa, «Los intelectuales argentinos y España: de la Generación del '37 a Ricardo Rojas», Anales de Literatura Hispanoamericana, 40, 2011, pp. 91-108.

MORENO LUZÓN, «Reconquistas América para regenerar España. Nacionalismo español y Centenario de las independencias en 1910-1911», Historia Mexicana, 237, junio-septiembre de 2010, pp. 561-640.

MORILLAS VENTURA, Enriqueta (ed.), España y Argentina en sus relaciones literarias, Universitat de Lleida, Lleida, 2002.

MOYA, José, Primos y extranjeros. La inmigración española en Buenos Aires, 1850-1930, Emecé, Buenos Aires, 2004.

MYERS, Jorge, «La revolución en las ideas: La generación romántica de 1837 en la cultura y la política argentinas», en Noemí Goldman (dir.), Nueva historia argentina. Tomo 3. Revolución, República, Confederación (1806-1852), Sudamericana, Buenos Aires, 2005, pp. 381-445.

NIÑO RODRÍGUEZ, Antonio, «Hispanoamericanismo, regeneración y prestigio nacional (1898-1931)», en Pedro Pérez Herrero y Nuria Tabanera (coordinadores), España-América Latina: un siglo de políticas culturales, AIETI/Síntesis-OEI, Madrid, 1993.

NÚÑEZ SEIXAS, Xosé Manoel, «¿Negar o reescribir la Hispanidad? Los nacionalismos subestatales ibéricos y América Latina, 1898-1936», Historia Mexicana, 265, 2017, pp. 401-458. 
España como caleidoscopio. Observaciones de intelectuales argentinos...

PAYÁ, Carlos y Eduardo Cárdenas, El primer nacionalismo argentino en Manuel Gálvez y Ricardo Rojas, Peña Lillo Editor, Buenos Aires, 1978.

RAMA, Carlos, Historia de las relaciones culturales entre España y América Latina. Siglo XIX, Fondo de Cultura Económica, México, 1982.

RAMOS, Julio, Desencuentros de la modernidad en América Latina. Literatura y política en el siglo XIX, Fondo de Cultura Económica, México, 1989.

RAMOS, Julio, «Hemispheric Domains: 1898 and the Origins of Latin Americanism», en Journal of Latin American Cultural Studies, 3, 2001 , pp. 237-251.

RIVADULLA BARRIENTOS, Manuel, La amistad irreconciliable: España y Argentina, 1900-1914, Editorial Mapfre, Madrid, 1992.

SÁENZ HAYES, Ricardo, Miguel Cané y su tiempo (1851-1905), Editorial Guillermo Kraft Limitada, Buenos Aires, 1955.

SÁNCHEZ MANTERO, Rafael et al., La imagen de España en América: 18981931, Escuela de Estudios Hispano-Americanos/Consejo Superior de Investigaciones Científicas, Sevilla, 1994.

SEPÚLVEDA MUÑOZ, Isidro, «Medio siglo de asociacionismo americanista español (1885-1936)», Espacio, Tiempo y Forma, 4, 1991, pp. 271-290.

SEPÚLVEDA MUÑOZ, Isidoro, El sueño de la madre patria: hispanoamericanismo y nacionalismo, Marcial Pons, Madrid, 2005.

TERÁN, Oscar, «El primer antiimperialismo latinoamericano», en Id. En busca de la ideología argentina, Catálogos, Buenos Aires, 1986, pp. 85-97.

THIESSE, Anne-Marie, La creación de las identidades nacionales. Europa: siglos XVIII-XX, Ézaro, Madrid, 2010.

ZULETA ÁLVAREZ, Enrique, España en América. Estudio sobre la historia de las ideas en Hispanoamérica, Editorial Confluencia, Buenos Aires, 2000.

ZULETA, Ignacio, La polémica modernista: el modernismo de mar a mar (18981907), Instituto Caro y Cuervo, Bogotá, 1988.

ZULUETA, Jesús Manuel, Viajeros hispanoamericanos por la España de fin de siglo (1890-1904), Universidad de Cádiz, Cádiz, 2002.

\section{Financiación}

Este trabajo forma parte de los resultados del proyecto «La patria hispana, la raza latina. Intelectuales, identidades colectivas y proyectos políticos entre España, Italia y Argentina (1880-1945)», financiado por el Ministerio de Industria, Economía y Competitividad (HAR2016-75324-P). 


\section{Datos de la autora}

Paula Bruno (Buenos Aires, Argentina, 1975) es Doctora en Historia por la Facultad de Filosofía y Letras de la Universidad de Buenos Aires. Es investigadora del Consejo Nacional de Investigaciones Científicas y Técnicas (CONICET, Argentina) y Profesora Investigadora Asociada de la Universidad Torcuato Di Tella, Buenos Aires, Argentina. Ha sido investigadora visitante en las siguientes casas de estudio: École des Hautes Études en Sciences Sociales (Paris), European University Institute (Firenze), Universidad Complutense de Madrid, Madrid Institute for Advanced Study (MIAS), Universitat de Barcelona, Universitat de Girona, Instituto de Investigaciones Dr. José María Luis Mora (Ciudad de México), Universidad Nacional Autónoma de México, Università degli Studi di Venezia "Ca' Foscari», Università degli Studi di Verona, Instituto Iberoamericano de Berlín, entre otras. Ha recibido los siguientes reconocimientos por sus obras: Premio Pensamiento de América "Leopoldo Zea», Premio Especial "Eduardo Mallea» y Premio "Gregorio Weinberg». 